\title{
Recognising Non-formal and Informal Learning: Typology and Comparison of Selected European Approaches
}

\author{
Silvia Annen \\ Federal Institute for Vocational Education and Training, Germany
}

\begin{abstract}
In Europe the topic recognition of informal learning becomes more and more important [1]. At the same time the Europe-wide as well as the national approaches dealing with recognition are rather diverse. To present the results of a systematic analysis of selected European approaches is the aim of this paper. Furthermore a synoptical comparison of these practical examples is presented. Due to the fact that the existing approaches have not been integrated in a consistent Europe-wide strategy for the recognition of competences, the systematic comparison of the approaches shall provide a basis for appropriate recommendations. In this paper selected European approaches for the recognition of informal learning are analysed, classified and evaluated with the help of the following theoretically derived criteria: objectives, methods, norms and standards, stakeholders, rights of disposal, coordination as well as signaling and screening.
\end{abstract}

\section{Introduction}

To theoretically conceptualise and analyse the recognition of informal learning beyond a mere descriptive level an institutional research perspective is required. So to examine the recognition of informal learning not only pedagogical theories but especially institutional theoretical approaches are relevant. Besides the competence theory and the certification theory the theoretical basis of the analysis is formed by the institution theory (particularly New Institutional Economics) and the governance approach [2; 3].

To identify differences and similarities as well as strengths and weaknesses of the analysed approaches on the basis of a theoretically derived criteria grid three ideal approach models are developed and used as theoretical benchmark for the analysis. The different approaches of recognition can be classified within a typology. This typology differentiates between the three ideal types 'Integration', 'Autonomy' and 'Secondation' (Figure 1). The integrative type is characterized by his connection to the formal educational system. Approaches which belong to the autonomous type provide a certification while they are not anchored within the formal educational system. In contrast approaches of the type 'Secondation' are marked, because they don't provide any certification or formal recognition, but they support this. These three types are also used to enhance and advance the analysed approaches and to structure the research area.

The above mentioned criteria derive from an analysis of different theoretical approaches [4]. Within this paper the chosen approaches, which are representatives for the above ideal types, are briefly introduced. The main results of a detailed analysis are here presented in a synoptical overview.

\begin{tabular}{|l|l|l|}
\hline Type Integration & Type Autonomy & Type Secondation \\
\hline $\begin{array}{l}\text { Obtainment of } \\
\text { certificates/ } \\
\text { qualifications of } \\
\text { the formal } \\
\text { educational } \\
\text { system }\end{array}$ & $\begin{array}{l}\text { Obtainment of } \\
\text { certificates without } \\
\text { any equivalence in } \\
\text { the formal } \\
\text { educational system }\end{array}$ & $\begin{array}{l}\text { Approaches for the } \\
\text { identification and } \\
\text { validation of } \\
\text { informal learning }\end{array}$ \\
\hline Formal & Non-formal & Informal \\
\hline $\begin{array}{l}\text { Summative (and } \\
\text { formative) }\end{array}$ & Summative & Formative \\
\hline $\begin{array}{l}\text { Assessment of } \\
\text { equivalences }\end{array}$ & $\begin{array}{l}\text { Tests, performance } \\
\text { measurements }\end{array}$ & $\begin{array}{l}\text { Competence } \\
\text { balances, portfolios }\end{array}$ \\
\hline Norm-orientated & Criteria-orientated & $\begin{array}{l}\text { Individual- } \\
\text { orientated }\end{array}$ \\
\hline
\end{tabular}

Figure 1. Typology of recognition approaches

\section{Theoretical basis and methodology}

In this paper methodological as well as politicalinstitutional aspects shall be regarded within the analysis of four selected exemplary approaches to recognition. Besides the competence theory and the certification theory the theoretical basis of the analysis 
is therefore formed by the institution theory [2] and the governance approach [3].

The within the institution theory contained distinction between institutions 'with stakeholders' and institutions 'without stakeholders' forms the basis for the analysis of the criteria 'stakeholders' as well as 'norms and standards'. Furthermore rights of disposal are relevant within the institutional economical analysis. The rights of disposal are here displayed as "rights of disposal to take a decision" and the ones of the individual as entitlements. This corresponds to a sociological understanding of rights of disposal. The New Institutional Economics as well as the Governance-Theory distinguish ideal between the following coordination mechanisms: hierarchy, market and network. These mechanisms are used as a reference point of the analysis of the approaches' coordination.

The process of the recognition of informal learning gives rise to a particular interaction structure involving a reciprocal Principal-Agent relationship between an individual and the body according recognition. Such a constellation entails two informational asymmetries characteristic. [4].

The first of these informational asymmetries relates to the competences of the individual in the recognition process. Within the context of the recognition of informal learning, competences are defined as dispositions. This implies that competences are not directly observable and may only be derived indirectly. The recognising bodies are not fully informed of the competences of the individuals and neither are these competences directly observable.

The second informational asymmetry relates to the methods and criteria of the recognising body. Special methods are deployed to make visible competences acquired via an informal pathway. These procedures should be conducted in accordance with certain standards and be professionally managed. Individuals are not (fully) familiar with the process adopted within this procedure. The individuals are not fully informed of the methods and criteria of the recognising body and are not able to evaluate the quality of the procedure.

The first informational asymmetry with regard to competences may be removed of individuals represent their competences (signalling). Appropriate evidence (references, work certification or other forms of evidence) provide a possible vehicle for passing on information in respect of their competences. For its part, the recognising body may deploy competence assessment procedures in order to determine the ability of the individual (screening).

The second informational asymmetry with regard to the quality of the procedure and the methods and criteria used may be reduced if the recognising body makes information available on quality standards applied within the scope of the procedure and thus ensures transparency in respect of methods and criteria (signalling). This also includes reputation effects, evidence of membership of a network or organisationally specific unique features against the background of competition with other providers. Individuals are afforded the opportunity to explore the market of potential providers and decide on a recognising body or certain procedure. Information and advisory provision are of particular significance in this area. Figure 2 illustrates the double informational asymmetry in the process of recognition.

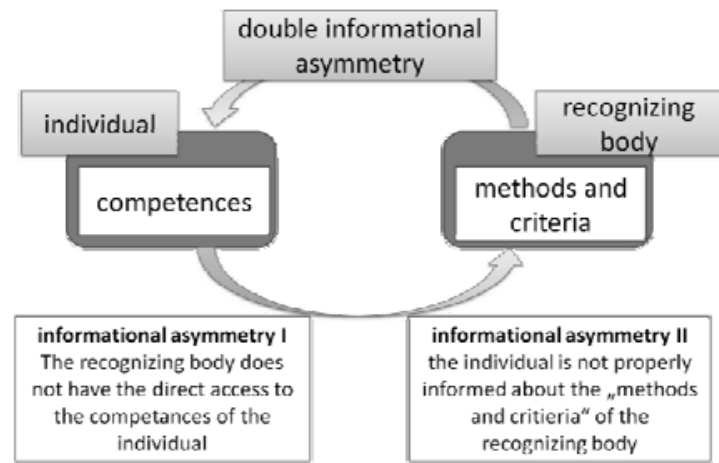

\section{Figure 2: Double informational asymmetry in the process of recognition}

The first informational asymmetry with regard to competences may be removed of individuals represent their competences (signalling). Appropriate evidence (references, work certification or other forms of evidence) provide a possible vehicle for passing on information in respect of their competences. For its part, the recognising body may deploy competence assessment procedures in order to determine the ability of the individual (screening). Performance can act as a basis for the recognising bodies to draw conclusions with regard to the competences of the individuals.

The second informational asymmetry with regard to the quality of the procedure and the methods and criteria used may be reduced if the recognising body makes information available on quality standards applied within the scope of the procedure and thus ensures transparency in respect of methods and criteria (signalling). This also includes reputation effects, evidence of membership of a network or organisationally specific unique features against the background of competition with other providers. Individuals are afforded the opportunity to explore the market of potential providers and decide on a recognising body or certain procedure. Information and advisory provision are of particular significance in this area.

The presented results have been achieved through three methodical components. Firstly the approaches have been analysed within an extensive literature 
research. Secondly an analysis of documents was carried out. Therefore, the documents, which are available regarding the approaches, have been evaluated with the help of the above analysis criteria. Among these documents are, for instance, handbooks, guidelines, quality assurance material, compendia and laws. Finally the results of the literature research and the analysis of documents were validated by interviewing important key persons regarding every approach. These persons played a decisive role in the context of the development of the approaches or in the implementation of the approach in practice. Besides the purpose of validation the interviews serve the collection of data concerning the experiences with the approaches.

\section{Selected European approaches for the recognition of informal learning}

Against the background of the above theoretical and conceptional considerations now selected European approaches towards the recognition of competences are presented. The approaches were chosen to give an exemplary overview of the different approaches and to represent different types regarding the above typology. Concrete the analysed approaches were chosen with regard to three main criteria:

1. Representativeness for special European educational systems respectively learning cultures

2. Relevance of the approaches within their context

3. Diverseness of the approaches in general.

The Netherlands have broad experience regarding intruments and methods to record and assess formal, non-formal and informal competences. For the implementation of the so called ,Erkenning Verworven Competenties' a global infrastructure was developed, e.g. the ,Kenniscentrum voor Erkenning Verworven Competenties' in Utrecht (cf. www.kenniscentrumevc.nl). This centre ties knowledge about and experiences with the EVCapproach and it informs about the approach. Meanwhile in the context of EVC a nationwide accepted quality code was developed, which every institution using the approach should maintain. The EVC-approach pursues the objective to recognize competences, which were acquired formal, non-formal or informal. Within this approach existing competences are ascertained, assessed and certified. This shall offer the individual the basis for its personal development of competences [5].

The approach is characterized by a strong orientation towards individual knowledge, skills and competences, for which reason formal qualifications are not central. Furthermore learning routes play a major role neither regarding the ascertainment of the competences nor regarding the further development of the individual competences. Although the EVCapproach first of all focuses on the ascertainment and the recognition of the individual competences, the individual's potentials are also analysed. Actually the EVC-regulations and procedures are mainly targeted on a formal recognition, that is to produce an equivalence between the individual competences and the formal qualifications or part-qualifications of the Dutch National Qualifications Framework [5].

According to the information of the EVC Knowledge Centre between 20,000 and 30,000 people participate in an EVC-approach every year, mainly on the level of MBO-schools. More detailed information about the numbers of participation is not available (cf. www.oecd.org/netherlands/41680313.pdf).

In 1986 the National Vocational Qualifications (NVQs) were introduced in England. They are jobrelated, competence-based or outcome-related qualifications that reflect the knowledge and skills that are required to perform a certain vocational activity. National occupational standards that are performance descriptions of what a competent person should be able to do in a particular profession provide the basis for the NVQs, which do not have to be completed within a specified period or a specific learning environment. NVQs consist of units that may be acquired when the learner is ready for an appropriate examination, regardless of how and where this knowledge, skills and competencies have been acquired. Ideal the conduct of the proceedings for the acquisition of an NVQ is as follows. The examiner supports the candidate in identifying his/her skills, selecting the appropriate standards, analyzing the learning processes still required and the corresponding required learning activities prior to the completion of an NVQ. First a reflection of past and current work experience takes place. Acquired competences are identified and a portfolio with supporting documents is created thereafter (learning diaries, letters of reference, work samples, etc.). Usually the verification of NVQs is based on an observation in the workplace, a survey and the preparation of a portfolio. The examiners and the entire process will be monitored by so-called 'external verifiers' to ensure that they apply the criteria in different places in the same way. Depending on which competences are required NVQs are divided into five levels [6].

Statistical data relating to the qualifications in the UK are only hardly available due to the lack of a unitary national system. According to the statistics of the former Department for Education and Skills just slightly more than a half of the 621.800 assigned NVQs and SVQs were awarded to learners above the age of 25 who entirely or partly received them through the recognition of formerly informal or non-formal learning [6]. 
The Loi de modernisation sociale of 2002 is the foundation of the Validation des Acquis de l'Expérience in France and enables anyone who has been in paid, unpaid or voluntary work for at least three years to have their occupational and personal experiences recognised and be awarded an appropriate official qualification. All relevant organisations have been required to develop procedures for the enactment and implementation of the VAE legislation [7].

The decree which followed the law of 2002 stipulates five essential stages within the VAE system [8]: 1. Information on the VAE process provided by regional centres, national information systems (e.g. www.vae.gouv.fr) and the educational organisations. 2. Decision on the permissibility (recevabilité) of the application in the form of the duration of the occupational experience in relation to the content of the qualification (fundamental criterion is evidence of occupational experience extending over a period of at least three years). 3 . The candidate compiles a portfolio or dossier describing his or her experiences. This may comprise an observation made by the candidate within his or her work situation or in a simulation or constitute other forms of evidence. This phase offers opportunities for candidates to receive mentoring and funding. 4. Interview/dialogue with a jury at the request of the jury or of the candidate (only mandatory in the higher education sector). 5. Consideration and decision by the jury on the basis of the documents produced and their own observations. Issue of diplomas, certificates and qualifications [9].

The VAE concept has gradually developed, and its introduction may today be evaluated as having been relatively successful. Evidence for this is reflected in the number of users. But the number of certifications awarded via VAE is extremely low compared to the total number of qualifications issued in France [10]. All diploma awarding ministries permitted just under 75,000 dossiers in 2009. 58,000 of these dossiers were evaluated by a jury. From 2002 to 2009 about 136,000 candidates gained recognition via using the VAE (cf. http://media.enseignementsup-recherche.gouv.fr/file/ 2010/98/7/VAEdans_ensemble_des_ministeres_16098 7.pdf).

Recognition of competences is involved in a long tradition in Norway. In 1999, the Norwegian strategy for lifelong learning began with the competence reform. In the same year, the national validation project was started to create a national system for validation and formal recognition of formal, nonformal and informal learning (in Norway called Realkompetanse). During the three-year national project, several local development projects were carried out. In this context, various methods and instruments have been developed. This was done in three sectors: in the formal education system, in the private sector as well as in the so-called third sector. The qualitative and quantitative data from these development projects as well as other surveys formed the basis of the new Norwegian legal framework. This is linked with the relevant laws of the educational system and the rights of individuals. In the years 2000 to 2005 , a total of about 60,000 people participated in a recognition procedure in the field of higher secondary education, of which about $80 \%$ were carried out in relation to vocational subjects [11].

In the field of higher education about 6,000 persons aged 25 years and older applied for admission to a study program in 2001 (the first year in which this was possible). In subsequent years, this number decreased to 2,700 in 2006. From 2001 to 2006, 50 to $70 \%$ of the applicants for the study program of their choice were found to be qualified. In competition with other students, 45 to $50 \%$ of applicants, which aimed at recognition, were admitted to the desired study program. Students who were admitted due to the recognition of formal, non-formal and informal learning take a share of about $5 \%$ of all students (www.oecd.org/norway/41782275.pdf).

The EVC-approach, the NVQs, the VAE and the Realkompetanse-approach can be assigned to the type 'Integration' because they are targeted on an obtainment of certificates respectively qualifications of the formal educational system. The other criteria of the above typology are also met, which is concretised within the synoptical comparison of the approaches.

With the development of the European Business Competence Licence (EBC*L), the goal was to create an internationally recognized standard for economic education. This examination and certification tool keeps records that the owner has at least basic knowledge of business and management.

The international EBC*L Center in Vienna and the Curatorship Business Competence for Europe in Paderborn organizationally stand behind the EBC*LSystem. At the national level, the approach is implemented by the country representations of the EBC*L and the EBC*L examination centers.

Only accredited educational institutions are authorized, in accordance with internationally valid standards and using specially trained personnel, to carry out EBC*L examinations and to offer EBC*L preparation courses. The EBC*L-system consists of a unitary curriculum that leads to an internationally accepted catalogue of learning targets.

In Total, the EBC*L concept embraces three levels. Level A provides general knowledge of professionals in manufacturing, sales and administration. The teaching of planning knowledge to key personnel with planning expertise, however, is the target of level B. According to schedule, management skills for executives are to be taught at level C as of 2011, which 
is not yet the case. The EBC*L certificates are acquired in handwritten two-hour tests in accredited EBC*L examination centers. The tests are related in content to the corresponding $\mathrm{EBC}^{*} \mathrm{~L}$ learning target catalogues. In preparation for the $\mathrm{EBC}^{*} \mathrm{~L}$, there are different offers, such as seminars of accredited examination centers, books and e-learning programs. Currently, the $\mathrm{EBC}^{*} \mathrm{~L}$ can be acquired in 31 countries in 25 languages. The $\mathrm{EBC}^{*} \mathrm{~L}$ certificate has been acquired by more than 10,000 people (cf. www.wirtschaftsfuehrerschein.at and www.ebcl.de ).

The European Computer Driving Licence (ECDL), known internationally as ICDL, is an internationally recognized certificate for computer users. The aim of the certificate is to certify knowledge about computer skills and certain widely used standard computer applications.

The international coordination is in the hands of the ECDL Foundation, a nonprofit organization based in Dublin, which monitors compliance with current international ECDL standards and which further develops the ECDL continuously. The ECDL is published by 30 European companies for computer science. The implementation in each country is up to the national contractors of the ECDL Foundation. Experts of the 148 participating countries update the syllabus of the ECDL regularly. The current version 5.0 dates from the year 2008 .

The contents of the certificate are aimed at the basic skills needed to operate a computer, with the ECDL syllabus being formulated product-neutral. The ECDL certificate is not supposed to certify specialists but non-specialists. These exams are conducted worldwide according to a uniform standard (cf. www.dlgi.de/uploads/media/ECDL_Syllabus_5_0_EC DL_DE.pdf ).

Under the so-called ECDL Core, seven complementary modules are tested and certified. Once these 4 out of 7 freely selectable modules have been successfully passed, the user receives the so-called ECDL Start. The 'ECDL Advanced' additionally certifies more extensive knowledge in one or more standard application as needed by advisors of IT users.

ECDL exams are conducted exclusively by ECDL examination centers which have been approved by the national organization. Exams are usually carried out on the PC and under the supervision of exam conductors. There are different possibilities to prepare for the ECDL tests. In addition to Internet services, print and online media as well as special courses accredited by educational institutions are offered. In February 2009, the number of ECDL participants amounted to nine million (cf. www.dlgi.de).

A framework of a comprehensive certification procedure which is according to the European norms regulates the Advanced IT Training of Specialists in private enterprises in Germany [12]. The Personnel Certification within the Advanced IT Training System (in the further course abbreviated AITTS) confirms and continually validates the competence of an individual which is used coping with given assignments within real IT business processes and their associated qualification requirements. Actually cert:it (cf. www.cert:it.org) is the only accredited certification body [13; 12]. The certification procedure for IT Specialists follows the international norm for personnel qualification ISO/IEC 17024 as well as the technical and qualitative standards supervised by the IT Sectoral Committee of the German Accreditation Authority. This Committee developed the so called 'Normative Document' which regulates and specifies form and content of the implementation of certification for IT Specialists (cf. www.kibnet.org/fix/doc/Normatives\% 20Dokument_Version\%202.1.1.pdf ). The Specialists' Profiles were restructured in 2009 whereas their number was reduced from 29 to 14 . In the course of doing so cert:it developed further normalising documents like e.g. the new examination regulation (cf. www.cert-it.com/fileadmin/redaktion/Cert-IT/ITSpezialisten/Allgemeine_Zert.-Unterlagen/Pruefungs ordnung.pdf).

The candidates acquire their competences while working in a real project at the workplace. The implementation of the project is documented according to a specific structure aligned to quality assurance requirements of the certification procedure (cf. www.cert-it.com/downloads/downloads-it-

spezialisten). Within the AITTS so called 'Reference Processes' were developed as templates for the qualification project (cf. www.cert-it.com/fileadmin/ redaktion/Cert-IT/IT-Spezialisten/Informationen_zur_ APO/Die_IT-Spezialisten-Prozesse_und

Kompetenzen.pdf). They define and delineate each of the 14 Specialist's Profiles. The Reference Processes constitute the curriculum and bring qualification and certification together.

The participant is supported by a coach or facilitator throughout the entire time. Furthermore technical experts who are in general experienced colleagues, employees or other participants and a complementary media structure facilitate the learning process (cf. www.kibnet.org/fix/doc/Normatives\% 20Dokument_Version\%202.1.1.pdf). At the latest two years after the start of the qualification process the candidates present their projects to examiners named by cert:it. The examination consists of making the documentation of the implementation available and of the completion of a technical talk [12] (cf. www.certit.com/fileadmin/redaktion/Cert-IT/IT-Spezialisten/

Allgemeine_Zert.-Unterlagen/Pruefungsordnung.pdf; a simulation of such an expert talk can be seen on http://www.cert-it.org/index.php?article_id=41\#). The 
European Business Competence Licence, the European Computer Driving Licence and the AITTS must be assigned to the type 'Autonomy' because it is targeted on an obtainment of certificates without any equivalence in the formal educational system and it meets also the other criteria of this ideal type.

In the context of the Lifelong Learning Program of the German Federal-State Commission for Educational Planning and Promotion of Research the ProfilPASSSystem was developed. This was based on an analysis of existing German and international training passes. The development-based ProfilPASS serves as a systematic identification, documentation and selfassessment of skills and competencies, regardless of the learning context. In addition, it is the intention of the ProfilPASS, to motivate the users to develop educational, vocational or everyday life-related targets [14].

This process requires a critical reflection on the skills and competencies by the individual. With regard to the developmentof personal objectives, the method requires the estimation of developments andrequirements in the future. With regard to the development of personal targets, the method requires the estimation of developments and requirements in the future. The aim of the ProfilPASS is to promote the awareness of personal strengths and weaknesses, through an accompanied development of an individual competence profile. In addition to the ProfilPASS document itself, the ProfilPASS-System contains a consulting concept. The individual should be supported by qualified consultants to deal with his/her biography (biographical approach). The entire system is coordinated by Germany's national ProfilPASS service department. Besides the trained ProfilPASS consultants there are currently trained more than 50 ProfilPASS dialogue centers [15].

Based on biographical stations as a result of the ProfilPASS procedure an individual certificate of competence the individual can make use of is developed to present themselves to a third party. Aims and individual action plans are drafted on the basis of the individual proof of qualifications. So far 54,764 ProfilPASS folders and 53,043 folders of the ProfilPASS for young people were issued [15] (cf. http://www.bildungsforschung.org/index.php/bildungsf orschung/article/view/92/94).

The Swiss CH-Q Competence-ManagementModel provides people the opportunity to capture, to evaluate and to eventually recognize their competences systematically. This serves as a basis for the individual path of development in the areas of education and occupation. Furthermore the professional flexibility and mobility will be promoted. The handbook associated with the $\mathrm{CH}-\mathrm{Q}$ approach consists of two parts - a working manual dealing with the instruments as well as a folder, which is used as a systematic collection and classification of qualifications, notes and files. In combination with the $\mathrm{CH}-\mathrm{Q}$-qualification book, the process is first accompanied by identification and assessment and it ends with recognizing competences. Specially trained advisors accompany the candidates[16].

With regard to the methodological design, the $\mathrm{CH}$ Q approach includes the archiving of formal qualifications and skills acquired individually. On the other hand, the documentation is the reflection of the individual competence profile of a user. On the basis of this reflection process, possible deficits and necessary appropriate measures can be derived. The processing of the manual can be carried out by both the users themselves as well as in directed learning processes (for example, in the framework of company seminars) or under the guidance of a trained advisor. When the users themselves are preparing a portfolio, particularly documents on training and other competences and skills acquired serve as a basis, which will be supplemented by a CV. In case the portfolio is created with the help of career or professional advisers, dialogue-based methods are used mostly [16].

In France the access to the bilan de compétences is legally regulated since 1991. The approach wants to offer people the opportunity to analyse their professional and personal competences, skills and motivations. On this basis a professional project or if applicable a corresponding further training measure is fixed. The bilan means a kind of educational leave, which is connected with an educational consultation. The creation of a bilan can be initialised by an employee respectively a jobless person or by the employer respectively the work agency, while the person always has to agree [17].

The whole process can be structured in three phases. Within the so called pre-phase the candidate is informed about the approach and agreements towards the concrete proceedings and the aims are made. Within the following phase of realisation the individual's professional and personal motivations and interests are analysed and reviewed regarding professional development options. Concrete methods in this phase are psychometric tests, work samples, biographic-discursive approaches or assessmentelements. The results of this phase are the basis for the final phase. In this last phase a so called synthesis paper is created, which documents the circumstances as well as the individual competences and skills regarding professional aims of the candidate. Furthermore it shows possible steps of realisation [17].

Teams of psychologists, pedagogues and personnel with other social professions always organise the above process, which is free of charge and voluntary. In general public, private and mixed financed centres 
operating the bilan exist. The so called Centres Interinstitutionelles de Bilan de Compétences (CIBC) have the longest tradition, which had the biggest market share in the past, but become less important. In the year 2008 the claiming of educational leave for a bilan de compétences rose $2 \%$ compared to 2007. In 2008 OPACIF received 30.267 applications for financing a bilan whereof only $2 \%$ were rejected. The costs for the service bilan can be very different depending on the centre ([17]; http://www.pratiquesde-la-formation.fr/Bilan-de-competences.html; http:// www.fongecif-idf.fr/fileadmin/user_upload/pdf/ guide_pratique_bilan_de_competences_07.pdf).

The ProfilPASS-System, the CH-Q CompetenceManagement-Model and the bilan de compétences are assigned to the type 'Secondation' because they are focused on the informal learning of the individuals using these approaches and they are not targeted on an obtainment of certificates. The results show that within one country more than one ideal type can exist, like the AITTS and the ProfilPASS-System in Germany or the VAE and the bilan de compétences in France.

\section{Synoptical Comparison of the selected approaches}

Regarding the approaches' methodological design (table 1) one can determine that the approaches belonging to the type 'Integration' and 'Secondation' use very similar methods. Thereby the methods used within the ideal type 'Integration' are broader and this approach covers all phases of the recognition process. This evitable deficit of the approaches of the ideal type 'Secondation' could be obliterated by another formation of the institutional structures. This affects the stakeholders on the one hand and the norms and standards on the other hand. The achievement of a certification and especially a formal recognition is obviously connected with a summative orientation of the approach. Furthermore a third party has to participate in the approach to integrate these two steps.

One main advantage of the approaches belonging to the ideal type ,Secondation' is that they cope best with the requirements of non-formal and informal learning. In contrast the approaches belonging to the ideal type 'Integration' stand out due to the fact that they cover the whole process of recognition.

All approaches that represent the ideal type 'Autonomy' are methodological rather limited, because they don't contain any self-assessment and they are focused mainly on one method - especially the ECDL. Furthermore the autonomous approaches only cover parts of the whole process of recognition. But one strength of these approaches is that within them individual competences are really measured by evaluating the individual's performance. This element can also be part of the approaches belonging to the type 'Integration' - depending on the individual case. The following table 1 provides an overview of the methodological design of all analysed approaches.

\begin{tabular}{|c|c|c|c|c|}
\hline Approach & $\begin{array}{l}\text { Methodo- } \\
\text { logical } \\
\text { Objective }\end{array}$ & $\begin{array}{l}\text { Type of } \\
\text { Assessment }\end{array}$ & $\begin{array}{l}\text { Concrete } \\
\text { Methods }\end{array}$ & Steps \\
\hline EVC & $\begin{array}{l}\text { summative } \\
\text { and } \\
\text { formative }\end{array}$ & $\begin{array}{l}\text { mostly third } \\
\text { party- and self- } \\
\text { assessment }\end{array}$ & $\begin{array}{l}\text { portfolio, } \\
\text { interview, } \\
\text { observation, } \\
\text { test }\end{array}$ & $\begin{array}{l}\text { identification, } \\
\text { assessment, validation. } \\
\text { certification, formal } \\
\text { recognition }\end{array}$ \\
\hline NVQs & $\begin{array}{l}\text { summative } \\
\text { and } \\
\text { formative }\end{array}$ & $\begin{array}{l}\text { mostly third } \\
\text { party- and self- } \\
\text { assessment }\end{array}$ & $\begin{array}{l}\text { portfolio, } \\
\text { interview, } \\
\text { observation }\end{array}$ & $\begin{array}{l}\text { identification, } \\
\text { assessment, validation, } \\
\text { certification, formal } \\
\text { recognition }\end{array}$ \\
\hline $\begin{array}{l}\text { Realkom- } \\
\text { petanse }\end{array}$ & $\begin{array}{l}\text { summative } \\
\text { and } \\
\text { formative }\end{array}$ & $\begin{array}{l}\text { mostily third } \\
\text { party- and self- } \\
\text { assessment }\end{array}$ & $\begin{array}{l}\text { portfolio. } \\
\text { interview, } \\
\text { observation }\end{array}$ & $\begin{array}{l}\text { Identification, } \\
\text { assessment. validation, } \\
\text { certification, formal } \\
\text { recognition }\end{array}$ \\
\hline VAE & $\begin{array}{l}\text { summative } \\
\text { and } \\
\text { formative }\end{array}$ & $\begin{array}{l}\text { mostiy third } \\
\text { party- and self- } \\
\text { assessment }\end{array}$ & $\begin{array}{l}\text { portfolio, } \\
\text { interview, } \\
\text { observation }\end{array}$ & $\begin{array}{l}\text { Identification, } \\
\text { assessment, validation, } \\
\text { certification, formal } \\
\text { recognition }\end{array}$ \\
\hline AITTS & summative & $\begin{array}{l}\text { third party- and } \\
\text { partly self- } \\
\text { assessment } \\
\text { (documentation) }\end{array}$ & $\begin{array}{l}\text { presentation, } \\
\text { expert talk }\end{array}$ & $\begin{array}{l}\text { assessment, validation, } \\
\text { certification }\end{array}$ \\
\hline EBC*L & summative & $\begin{array}{l}\text { third party- } \\
\text { assessment }\end{array}$ & test & $\begin{array}{l}\text { assessment, validation, } \\
\text { certification }\end{array}$ \\
\hline ECDL & summative & $\begin{array}{l}\text { third party- } \\
\text { assessment }\end{array}$ & $\begin{array}{l}\text { computer } \\
\text { based test }\end{array}$ & $\begin{array}{l}\text { assessment, validation, } \\
\text { certification }\end{array}$ \\
\hline Bilan & $\begin{array}{l}\text { rather } \\
\text { formative }\end{array}$ & $\begin{array}{l}\text { mostly third } \\
\text { party- and seli- } \\
\text { assessment }\end{array}$ & $\begin{array}{l}\text { multimodal } \\
\text { (interview, } \\
\text { porttolio, } \\
\text { tests etc.) }\end{array}$ & $\begin{array}{l}\text { Identification, } \\
\text { assessment }\end{array}$ \\
\hline $\mathrm{CH}-\mathrm{Q}$ & $\begin{array}{l}\begin{array}{l}\text { rather } \\
\text { formative }\end{array} \\
\text { for a }\end{array}$ & self-assessment & $\begin{array}{l}\text { portiflio. } \\
\text { dialogue }\end{array}$ & $\begin{array}{l}\text { identification, } \\
\text { assessment: validation } \\
\text { (only } \mathrm{CH}-\mathrm{Q} \text { level } 2,3 \text { and } \\
4 \text { ): certification (only } \mathrm{CH} \text { - } \\
\text { Q level } 2,3 \text { and } 4 \text { ) }\end{array}$ \\
\hline $\begin{array}{l}\text { Profil- } \\
\text { PASS }\end{array}$ & $\begin{array}{l}\text { rather } \\
\text { formative }\end{array}$ & self-assessment & $\begin{array}{l}\text { portfolio. } \\
\text { dialogue }\end{array}$ & $\begin{array}{l}\text { identification, } \\
\text { assessment }\end{array}$ \\
\hline
\end{tabular}

Regarding the analysis of the institutional design of the approaches the following criteria are relevant: political objectives, stakeholders, norms and standards, rights of disposal and coordination. The results of the analysis regarding these criteria are presented within the tables 2 and 3 .

While the approaches belonging to the ideal types 'Integration' and 'Autonomy' are more directed towards an utilization within the formal educational system and on the labour market, the approaches that belong to the type 'Secondation' are more directed towards the individuals and their advancement. The promotion of the concept of lifelong learning is one element that conjoins the approaches with each other. This aim is also of high relevance on the European political agenda (e.g. the Lifelong Learning Programme 2007-2013).

The three ideal types can be relatively clear classified regarding certain sectors. The integrative approaches have a broad network and integrate stakeholders from different sectors. In contrast the autonomous approach is more strongly anchored within the private sector, but with connections to the formal educational system. The approach representing the type 'Secondation' finally is mainly anchored within the non-profit sector. 
Table 2: Institutional design of the approaches I

\begin{tabular}{|c|c|c|c|}
\hline Approach & $\begin{array}{l}\text { Political } \\
\text { Objectives }\end{array}$ & $\begin{array}{l}\text { Stake- } \\
\text { holders }\end{array}$ & $\begin{array}{l}\text { Norms and } \\
\text { Standards }\end{array}$ \\
\hline EVC & $\begin{array}{l}\text { formal } \\
\text { qualification, } \\
\text { employability, } \\
\text { lifelong } \\
\text { learning }\end{array}$ & $\begin{array}{l}\text { formal } \\
\text { educational } \\
\text { system, } \\
\text { private sector, } \\
\text { non-profit- } \\
\text { sector }\end{array}$ & $\begin{array}{l}\text { occupational standards, } \\
\text { educational standards, } \\
\text { assessment standards; } \\
\text { process, output }\end{array}$ \\
\hline NVQs & $\begin{array}{l}\text { formal } \\
\text { qualification, } \\
\text { employability, } \\
\text { lifelong } \\
\text { learning }\end{array}$ & $\begin{array}{l}\text { private sector, } \\
\text { formal } \\
\text { educational } \\
\text { system }\end{array}$ & $\begin{array}{l}\text { occupational standards, } \\
\text { educational standards, } \\
\text { assessment standards; } \\
\text { process, output }\end{array}$ \\
\hline $\begin{array}{l}\text { Realkom- } \\
\text { petanse }\end{array}$ & $\begin{array}{l}\text { formal } \\
\text { qualification, } \\
\text { employability, } \\
\text { lifelong } \\
\text { learning }\end{array}$ & $\begin{array}{l}\text { formal } \\
\text { educational } \\
\text { system, } \\
\text { private sector, } \\
\text { non-profit- } \\
\text { sector }\end{array}$ & $\begin{array}{l}\text { occupational standards, } \\
\text { educational standards, } \\
\text { assessment standards; } \\
\text { process, output }\end{array}$ \\
\hline VAE & $\begin{array}{l}\text { formal } \\
\text { qualification, } \\
\text { employability, } \\
\text { lifelong } \\
\text { learning }\end{array}$ & $\begin{array}{l}\text { formal } \\
\text { educational } \\
\text { system, } \\
\text { (private sector } \\
\text { if in RNCP) } \\
\end{array}$ & $\begin{array}{l}\text { educational standards, } \\
\text { assessment standards; } \\
\text { process, output }\end{array}$ \\
\hline AITTS & $\begin{array}{l}\text { employability, } \\
\text { professionali- } \\
\text { sation in the IT } \\
\text { sector }\end{array}$ & $\begin{array}{l}\text { private sector, } \\
\text { (formal } \\
\text { educational } \\
\text { system) }\end{array}$ & $\begin{array}{l}\text { occupational standards, } \\
\text { assessment standards; } \\
\text { output, process, input }\end{array}$ \\
\hline EBC*L & $\begin{array}{l}\text { employability, } \\
\text { broad } \\
\text { education in } \\
\text { economics }\end{array}$ & $\begin{array}{l}\text { private sector, } \\
\text { formal } \\
\text { educational } \\
\text { system }\end{array}$ & $\begin{array}{l}\text { assessment standards; } \\
\text { output, process, input }\end{array}$ \\
\hline ECDL & $\begin{array}{l}\text { employability, } \\
\text { broad } \\
\text { education in } \\
\text { the IT field }\end{array}$ & $\begin{array}{l}\text { private sector, } \\
\text { formal } \\
\text { educational } \\
\text { system }\end{array}$ & $\begin{array}{l}\text { assessment standards; } \\
\text { output, process, input }\end{array}$ \\
\hline Bilan & $\begin{array}{l}\text { occupational } \\
\text { mobility, } \\
\text { strengthening } \\
\text { of the } \\
\text { individual, } \\
\text { lifelong } \\
\text { learning }\end{array}$ & $\begin{array}{l}\text { consultants, } \\
\text { public } \\
\text { institutions } \\
\text { (CIBCs), } \\
\text { private sector }\end{array}$ & $\begin{array}{l}\text { assessment standards; } \\
\text { process, input }\end{array}$ \\
\hline $\mathrm{CH}-\mathrm{Q}$ & $\begin{array}{l}\text { occupational } \\
\text { mobility, } \\
\text { empowerment, } \\
\text { lifelong } \\
\text { learning }\end{array}$ & $\begin{array}{l}\text { consultants, } \\
\text { non-profit- } \\
\text { sector, private } \\
\text { sector }\end{array}$ & $\begin{array}{l}\text { assessment standards; } \\
\text { process, input }\end{array}$ \\
\hline $\begin{array}{l}\text { Profil- } \\
\text { PASS }\end{array}$ & $\begin{array}{l}\text { strengthening } \\
\text { of the } \\
\text { individual, } \\
\text { lifelong } \\
\text { learning, } \\
\text { occupational } \\
\text { mobility }\end{array}$ & $\begin{array}{l}\text { consultants, } \\
\text { non-profit- } \\
\text { sector, in the } \\
\text { future if } \\
\text { applicable } \\
\text { private sector }\end{array}$ & $\begin{array}{l}\text { assessment standards; } \\
\text { process, input }\end{array}$ \\
\hline
\end{tabular}

Regarding the criterion 'stakeholders' the both last named approaches have potential to develop and to get anchored in the formal educational system. This is essential, because to achieve a formal recognition of competences the stakeholders of the formal educational system are mandatory to be engaged in the process or the existing rights of disposal (usually lying in their hands) have to be changed respectively adjusted. This comes along with a stronger orientation towards the corresponding standards. The approaches of the type 'Autonomy' and 'Secondation' indeed contain already assessment standards, but the orientation towards educational or occupational standards is not yet included.

The organisational rights of disposal within the integrative approaches lie exclusively in the hands of the stakeholders of the formal educational system, which leads for the individual to diplomas (or certificates) with a value in the formal educational system and on the labour market. The situation is different within both other approach types. They are characterised by accreditation structures within the system. But the individuals therefore only receive certificates that are mainly connected with entitlements within the approaches themselves and less within the formal educational system or on the labour market. In this regard cooperation and the location of the achieved certificates within a qualification framework might be beneficial.

Table 3: Institutional design of the approaches II

\begin{tabular}{|c|c|c|}
\hline Approach & Rights of Disposal & $\begin{array}{l}\text { Coordi- } \\
\text { nation }\end{array}$ \\
\hline EVC & $\begin{array}{l}\text { Organisational: awarding by all certifying } \\
\text { stakeholders } \\
\text { Individual: diploma, certificate, educational } \\
\text { system, labour market }\end{array}$ & network \\
\hline NVQs & $\begin{array}{l}\text { Organisational: awarding by awarding bodies } \\
\text { Individual: diploma; } \\
\text { educational system, (labour market), within } \\
\text { approach }\end{array}$ & $\begin{array}{l}\text { market, } \\
\text { network }\end{array}$ \\
\hline $\begin{array}{l}\text { Realkom- } \\
\text { petanse }\end{array}$ & $\begin{array}{l}\text { Organisational: } \\
\text { awarding by the stakeholders of the formal } \\
\text { educational system (and others) } \\
\text { Individual: diploma, certificate, educational } \\
\text { system, labour market }\end{array}$ & $\begin{array}{l}\text { hierarchy, } \\
\text { network }\end{array}$ \\
\hline VAE & $\begin{array}{l}\text { Organisational: } \\
\text { awarding by the stakeholders of the formal } \\
\text { educational system } \\
\text { Individual: diploma, } \\
\text { educational system, labour market }\end{array}$ & $\begin{array}{l}\text { hierarchy, } \\
\text { network }\end{array}$ \\
\hline AITTS & $\begin{array}{l}\text { Organisational: } \\
\text { accreditation by German accreditation body, } \\
\text { awarding by cert-IT } \\
\text { Individual: certificate, within approach, } \\
\text { educational system, labour market }\end{array}$ & market \\
\hline$E B C * L$ & $\begin{array}{l}\text { Organisational: licencing by EBC*L } \\
\text { International, accreditation by national } \\
\text { representations, } \\
\text { awarding by asssessment centres } \\
\text { Individual: certificate, within approach }\end{array}$ & $\begin{array}{l}\text { market, } \\
\text { network }\end{array}$ \\
\hline ECDL & $\begin{array}{l}\text { Organisational: licencing by Foundation, } \\
\text { accreditation by national licencees, awarding } \\
\text { by assessment centres } \\
\text { Individual: certificate, within approach }\end{array}$ & $\begin{array}{l}\text { market, } \\
\text { network }\end{array}$ \\
\hline Bilan & $\begin{array}{l}\text { Organisational: accreditation by the financing } \\
\text { fund institutions, awarding by consulting } \\
\text { institutions } \\
\text { Individual: participation certificate }\end{array}$ & $\begin{array}{l}\text { market, } \\
\text { network }\end{array}$ \\
\hline $\mathrm{CH}-\mathrm{Q}$ & $\begin{array}{l}\text { Organisational: licencing or certification by } \\
\text { association } \mathrm{CH}-\mathrm{Q} \text {, awarding by providers } \\
\text { Individual: certificate of attendance, within } \\
\text { approach }\end{array}$ & $\begin{array}{l}\text { market, } \\
\text { network }\end{array}$ \\
\hline $\begin{array}{l}\text { Profil- } \\
\text { PASS }\end{array}$ & $\begin{array}{l}\text { Organisational: accreditation by national } \\
\text { service centre, awarding by dialogue centres } \\
\text { respectively consultants } \\
\text { Individual: certificate of attendance, within } \\
\text { approach }\end{array}$ & network \\
\hline
\end{tabular}

For the acceptance of an approach accreditation of institutions as well as quality assurance is a necessary precondititon which all approaches conform to. Within all approaches the rights of disposal are unequivocally distributed among the stakeholders, which is positive. They all allocate their rights of disposal via accreditation procedures. Furthermore the rights of disposal are unequivocally distributed among the stakeholders, which is positive. A disadvantage for the users of some approaches is the limited entitlements in the formal educational system connected with the certificates of the approaches. In this regard cooperation and the location of the achieved certificates within a qualification framework might be 
beneficial. Furthermore the analysis shows that the coordination mechanism network is relevant within every approach, but is or has to be complemented in most cases by the mechanisms market or hierarchy to motivate or obligate the relevant stakeholders to implement and to make use of the approaches. All analysed approaches have still potential regarding the provision of information, that is first of all making the procedures and standards used transparent for the individuals. This is very important, because the analysis shows that standards are relevant for the recognition in every approach. This aspect can be concretised in conjunction with the use of signaling and screening.

In general the results of the institutional design of the approaches show that in most cases a lot of stakeholders are involved and that therefore the coordination of these approaches is rather complex. Furthermore the analysis shows that the coordination mechanism network is relevant within every approach, but is or has to be complemented in most cases by the mechanisms market or hierarchy to motivate or obligate the relevant stakeholders to implement and to make use of the approaches. All analysed approaches have still potential regarding the provision of information, that is first of all making the procedures and standards used transparent for the individuals. This is very important, because the analysis shows that standards are relevant for the recognition in every approach.

Having a look at the results of the analysis regarding the aspects of signaling and screening (table 4) one can observe that the biggest deficit lies in the widely missing activities of the individuals regarding the information asymmetry II. Here the activity comes mainly from the recognising bodies. This is due to the limited opportunities of the individuals to gain information about the methods and criteria of the recognition. The recognising bodies could facilitate the situation for the individuals by providing more information, e.g. on homepages or in data bases.

\section{Table 4: Use of Signaling and Screening within the approaches}

\begin{tabular}{|l|l|l|l|l|}
\hline \multirow{2}{*}{ Approach } & \multicolumn{2}{|l|}{ Information asymmetry I } & \multicolumn{2}{l|}{ Information asymmetry II } \\
\cline { 2 - 5 } & $\begin{array}{l}\text { Activity of the } \\
\text { recognising } \\
\text { body }\end{array}$ & $\begin{array}{l}\text { Activity of } \\
\text { the } \\
\text { individual }\end{array}$ & $\begin{array}{l}\text { Activity of the } \\
\text { recognising } \\
\text { body }\end{array}$ & $\begin{array}{l}\text { Activity of } \\
\text { the } \\
\text { individual }\end{array}$ \\
\hline EVC & high & high & high & low \\
\hline NVQS & high & high & high & low \\
\hline Realkomp. & high & high & high & low \\
\hline VAE & high & high & high & low \\
\hline AITTS & high & high & high & low \\
\hline EBC*L & high & low & high & low \\
\hline ECDL & high & low & high & low \\
\hline Bilan & high & high & high & low \\
\hline CH-Q & low & high & high & low \\
\hline ProfilPASS & low & high & medium & low \\
\hline
\end{tabular}

Within the approaches belonging to the type 'Secondation' the activity of the recognizing bodies regarding the information asymmetry I is rather low. This allows the strong orientation towards the individual requirements of the users, but it also is problematic regarding the usability of the approaches' results in the formal educational system and on the labour market.

\section{Conclusion, recommendations and forecast}

Against the background of the analysis one can assume that the approaches belonging to the type 'Integration' contain the whole process of recognition from the identification of learning outcomes until their formal recognition, while the approaches belonging to the types 'Autonomy' and 'Secondation' only contain parts of this process. Furthermore the type 'Integration' is rather deeply anchored within the formal educational system and is focused on formal qualifications as reference points rather than on individuals and their competences. In contrast within both other types the individual learning outcomes gained within informal learning processes are in the focus more than formal qualifications. As a general result the contribution shows why the type 'Integration' can be recommended in every national context to offer people the opportunity to get their informal learning formally recognized. Moreover the two other types are relevant to take the individual in an adequate way into account within the process of recognition of informal learning. Regarding this the type 'Secondation' has strengths, while putting the individual in the focus of the recognition process. The type 'Autonomy' offers an intermediate solution. It uses qualification structures as references for the recognition while simultaneous being geared towards individual and informal learning processes. So the three types of approaches can be combined. The approaches belonging to the type 'Secondation' can be used in preparation of the use of an approach belonging to the type 'Integration'. That makes sense, because the latter often lack in elaborated and area-wide consulting systems. The approaches of the type 'Autonomy' can also complement the other ones by certifying and documenting competences, which are not part of the formal educational system, but which can be integrated in formal qualifications or in recognition procedures, which lead to formal qualifications.

Furthermore the analysis shows that educational or occupational standards are definitely needed, if a formal recognition should be done within the approach. In general the standardisation associated with the analysed approaches is positive. One distinctive advantage is that non of the approaches standardises or 
regulates the learning process which goes conform with the requirements of non-formal and informal learning and realises the Europe-wide intended orientation towards learning outcomes. Furthermore the approaches contain standards for the qualification of the personnel responsible for the certification. This seems to be an absolute essential measure because by placing learning outcomes at the centre of individuals' developmental paths new players automatically appear, such as evaluators or mentors, whose functions have hitherto been largely practiced by formally qualified teachers [18]. The rights of disposal are in the hands of the institutions of the formal educational system within the analysed approaches of the ideal type 'Integration'. If this is not the case there is a necessity of certain accreditation and awarding structures within the approaches. Regarding the coordination one can assume that the network mechanism is the most important one and becomes even more relevant.

The information asymmetry II is the main deficit, which the different countries have realised and are actually working on. Currently systems to support individuals in getting their competences recognised are missing and must be developed. Furthermore studies on the differences between the theoretical conceptualisation and the practical use of the approaches should be done. In general more empirical data on the costs and the value of the approaches is needed. It can be estimated that the discussions towards an European as well as a German Qualifications Framework will make it necessary to decide about the relationships between formal degrees and the certificates which result from the above analysed approaches and how they can be located within such frameworks. Furthermore one will have to clarify which institutional structure is necessary for this and how this will lead to a new allocation of the rights of disposal and to new forms of coordination.

The results also show that systems to support individuals in making their competences transparent and getting them recognised are missing and must be developed. Furthermore studies on the differences between the theoretical conceptualisation and the practical use of the approaches should be done. Overall more empirical data on the costs and the value of the approaches is needed. Here not only monetary but also transaction costs or opportunity costs for the individuals as well as for the institutions must be regarded.

\section{References}

[1] Werquin, P.: Terms, concepts and models for analysing the value of recognition programmes. Paris 2007.

[2] Richter, R./Furubotn, E.G.: Neue Institutionenökonomik: eine Einführung und kritische Würdigung. Tübingen 2003.
[3] Altrichter, H./Brüsemeister, T./Wissinger, J.: Educational Governance: Handlungskoordination und Steuerung im Bildungssystem. Wiesbaden 2007.

[4] Annen, S.: Anerkennung von Kompetenzen kriterienorientierte Analyse ausgewählter Verfahren in Europa. Bielefeld 2012.

[5] Hövels, B.: Kompetenzerfassung in den Niederlanden. Impulsreferat zum Workshop 'Kompetenzerfassungssysteme der Berufsbildung in Europa - Vorbilder für ein gemeinsames Modell?’. Brüssel 2010.

[6] Leney, T./Ponton, A.: OECD Thematic Review On Recognition Of Non-Formal And Informal Learning. Country Background Report. OECD (Hrsg.). Paris 2007.

[7] Haeringer, A.: The French APEL: Ambitious Procedures. In: Corradi, C./Evans, N./Valk, A. (Hrsg.): Recognising Experiential Learning: Practices in European Universities. Tartu 2006. pp. 83-94.

[8] ECOTEC: European Inventory on validation of informal and non-formal learning. Case Study: Role of the VAE jury. Birmingham 2007.

[9] Hawley, J.: European inventory on validation of informal and non-formal learning. France. ECOTEC (Eds.). Birmingham 2007.

[10] Charraud, A.-M.: The French approach of VPL. A historical approach and the state of the art in 2007. In: Duvekot, R. et al. (Eds.): Managing European diversity in lifelong learning. The many perspectives of the Valuation of Prior Learning in the European workplace. Nijmegen 2007. pp. 149-159.

[11] Mohn, T.N.: Valuation and Validation of non-formal and informal learning in Norway - experiences and challenges 2007. Oslo 2007.

[12] Grunwald, S./Beier, J.C.: Quality Assurance and Certification. Personnel Certification with the Advanced IT Training System. Berlin 2002.

[13] Grunwald, S.: Akkreditierung und Personalzertifizierung im IT-Weiterbildungssystem gemäß ISO/IEC 17024. In: Hochschule und Weiterbildung. 2004 Heft 1, S. 31-37.

[14] ECOTEC: European Inventory on Validation of informal and non-formal Learning. 2007 Update. A final report to DG Education and Culture of the European Commission. Otero, M.S./Hawley, J./Nevala, A.M. (Eds.). Birmingham 2008.

[15] BMBF (Hrsg.): Stand der Anerkennung non-formalen und informellen Lernens im Rahmen der OECDAktivität „Recognition of non-formal and informal Learning". Bonn/Berlin 2008.

[16] Haasler, B./Schnitger, M.: Kompetenzerfassung bei Arbeitssuchenden - eine explorative Studie unter besonderer Berücksichtigung des Sektors privater Arbeitsvermittlung in Deutschland. ITB-Arbeitspapier Nr. 57. Bremen 2005.

[17] Käpplinger, B.: Neue Zugänge zu Weiterbildung und Arbeit durch Kompetenzbilanzierungen? Erste Antworten aus Europa und Deutschland. In: REPORT (27) 1/2004. Darmstadt 2004. S. 117-123.

[18] Werquin, P.: Recognising non-formal and informal learning: outcomes, policies and practices. Paris 2010. 